\title{
REMEDIES FOR HARM CAUSED BY UN PEACEKEEPERS
}

\author{
Bruce Rashkow*
}

Editor's note: On February 26 of this year, the American Society of International Law, in cooperation with the United Nations Association-National Capital Area, the American Bar Association Section of International Law, and the Washington Foreign Law Society hosted a panel discussion" titled "Remedies for Harm Caused by UN Peacekeepers." The discussion focused generally on misconduct by UN peacekeepers that may result in harm to third parties and specifically on third-party claims in the context of the cholera epidemic in Haiti (including, for example, allegations of sexual exploitation and abuse by peacekeeping forces). The following is the first in a series of posts by the speakers of the panel.

\section{Remedies in response to harm caused by UN peacekeeping activities}

Since the creation of the United Nations, the need for the Organization to enjoy immunity from the jurisdiction of Member States has been widely recognized as necessary to achieve its important and far ranging purposes. However, it has also been understood that this immunity was not intended to shield the Organization from responsibility as a "good citizen" on the world stage to respond to justifiable claims against the Organization by third parties resulting from the activities or operations of the Organization. The United Nations has generally achieved these dual objectives, although two recent situations in the peacekeeping context have raised questions about whether it continues to do so, namely the cases involving the Mothers of Srebrenica and the Haiti Cholera victims.

Claims by third parties against the United Nations come from a broad range of claimants who allege to have been harmed in some way by the activities or operations of the United Nations. These claims are of generally of two types: Contractual or Tortious.

\section{Third-party claims, generally}

The norm with individual consultants, large and small contractors, and others who interact contractually with the United Nations, including in the peacekeeping context, is that they must seek to resolve their claims in some manner through Section 29 of the Convention on the Privileges and Immunities of the United Nations $^{2}$ (General Convention). That provision calls for a modality for resolving disputes of a private law character.

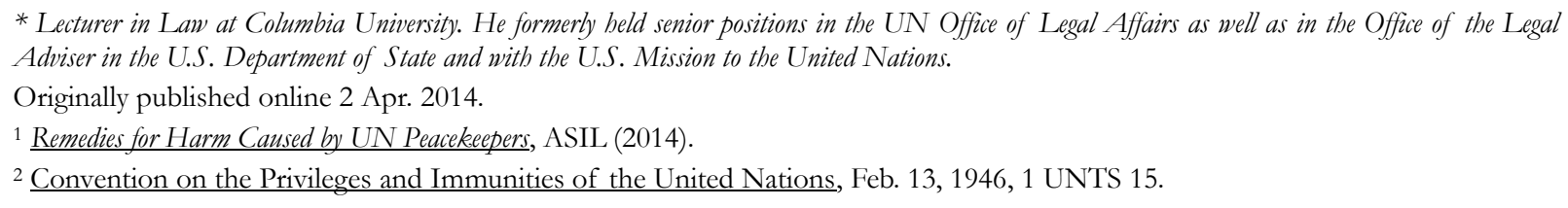


This normally means an initial effort to amicably resolve the dispute administratively (e.g., by a negotiated settlement). Failing such an amicable resolution, the parties would seek to resolve the dispute through arbitration, usually under the terms of the contract entered into with the Organization. Of course, the opportunity for arbitration, while attractive and useful to large commercial entities with large claims, is not so attractive to individual contractors or consultants. The United Nations is considering revising its newly reformed internal justice system to address such small claimants that would offer Ombudsman services and/or some form of streamlined, inexpensive arbitration process more appropriate for such smaller claims.

In regard to tort claims, initially, the focus was on automobile accidents involving UN vehicles or vehicles driven by UN staff or officials in the performance of official functions, including in the field. In addition, as the role of the United Nations expanded over the years in the area of peacekeeping and other field missions, it became necessary or desirable for the Organization to obtain its own air carrier capability, routinely through charter arrangements with providers of the aircraft, rather than rely on services provided by commercial entities or even Member States. In both instances, the United Nations has relied on worldwide insurance policies to address its exposure to risks of third-party claims, although in regard to air services it also seeks to protect itself by contractually shifting the risk to the provider.

In regard to third-party claims resulting from the operations and activities of operational subsidiary bodies of the United Nations in the field (e.g., UNDP and UNICEF), the Organization routinely enters into agreements with the beneficiary states where such activities occur to hold harmless the Organization in respect of claims that may arise in relation to its activities.

Over the years, for one reason or another, tort claims have usually been amicably resolved-without recourse to arbitration. That said, occasionally, the Organization has been sued or threatened to be sued in a national court. Such suits are inevitably either amicably resolved or dismissed on the basis of the Organization's immunity.

\section{Third-party claims in connection with peacekeeping}

With respect to peacekeeping missions, the Organization has internal administrative processes in place to deal with claims against it. Initially, these processes have included internal claims review boards the decisions of which may be challenged by requests for further administrative review within the Organization—or arbitration.

As a practical matter, these boards have worked well over the years to resolve claims on a day-to-day basis, even if at times their decisions have been challenged. The Status of Forces agreements ${ }^{3}$ (SOFAs) between the Organization and the states in which such peacekeeping missions take place also provide routinely for a standing claims commission. However, throughout the history of United Nations peacekeeping missions no such commission has ever been established.

In the late 1990s, however, in response to the growth in peacekeeping missions and related claims, the Organization adopted a special regime ${ }^{4}$ to deal specifically with third party contract and tort claims arising in the context of such missions. The Organization went to great lengths in designing this regime to balance the obligations of UN peacekeeping missions to respond to third-party claims with the obligations of the host country that invited such mission into the country to assume some responsibility in principle for such claims.

That balance resulted in certain types of claims being excluded altogether and limits being set on the damages for which the Organization would be liable in relation to certain contract and tort claims. The

${ }^{3}$ UN General Assembly, Model Status-of-Forces Agreement for Peace-keeping Operations: Rep. of the Secretary-General, UN Doc. A/45/594 (Oct. 9, 1990).

${ }^{4}$ G.A. Res. 52/247 (June 26, 1998). 
Organization established these financial limitations with the understanding that the host country would ultimately be responsible for compensation, if any, beyond these limits.

The regime excludes liability altogether for claims resulting from or attributable to activities of UN peacekeepers arising from "operational necessity." 5

The concept of "operational necessity" was developed specifically in connection with UN peacekeeping operations and, while similar to the more traditional concept of "military necessity," goes a bit further. ${ }^{6}$ Notably, the concept of "military necessity," governed by the laws of war, remains under the new regime as an exemption from liability specifically relating to combat operations.

The new regime imposes temporal and financial limitations on the liability of the Organization in terms of personal injury, illness, or death and for property damage resulting from or attributable the activities of peacekeeping operations in the performance of their official duties. In this last respect, it also excludes certain kinds of damages (e.g., non-economic loss).

The new regime recognizes that third-party claims may continue to be addressed, as they have in the past, by local claims review boards. It also preserves the long-standing but never invoked option for the establishment of a standing claims commission.

New challenges for the United Nations in responding to claims in the peacekeeping context: Mothers of Srebrenica and Haiti cholera

At this point we should briefly address the two most recent controversial liability challenges facing the United Nations: the Mothers of Srebrenica and the Haiti cholera cases. Underlying the efforts of the Organization throughout the years to amicably settle third-party claims has been the desire or goal of the United Nations not only to be a good citizen on the world stage — to be fundamentally fair in dealing with individuals injured in some manner as a direct result of UN actions-but also to avoid bad publicity. However, with the increase in peacekeeping activities and the evolution of more robust peacekeeping mandates since the end of the Cold War, the realities of such a more active engagement are raising new challenges. These challenges are perhaps most clearly reflected in the decisions of the United Nations in invoking immunity in the face of claims by the Mothers of Srebrenica and the Haitian cholera victims.

On the one hand, with the Mothers of Srebrenica, the issue is the failure of UN forces to protect innocent civilians from almost certain death in the face of a policy, if not mandate, to provide such protection. On the other hand, with the Haitian cholera victims, the issue is the ostensible negligence of the United Nations in failing to screen troops for cholera prior to deployment in Haiti or to properly maintain waste treatment facilities utilized by such troops that arguably caused a cholera outbreak that affected thousands of innocent civilians. In both cases, the Organization declined to accept responsibility to compensate the victims.

In the Mothers of Srebrenica case brought in Dutch courts, the United Nations maintained its immunity. The Dutch Supreme Court, overruling the Appellate Court, upheld immunity as absolute ${ }^{7}$, indicating that the assertion of immunity is not affected by the failure of the United Nations to provide a modality for bringing these claims under Section 29 of the General Convention.

The ruling of the Dutch Supreme Court raises a fundamental issue of the relationship of the claimed immunity under Section 2 of the Convention to the requirement under Section 29 for the United Nations to provide a modality for reviewing these claims. The ruling also raises the issue of what is meant under Section

${ }^{5}$ Id. at para. 6, as defined in para. 14 of GA Res. 51/389 (Sep. 20, 1996).

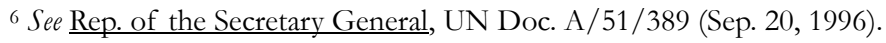

${ }^{7}$ HR 13 April 2012 (Mothers of Srebrenica/The State of the Netherlands) (Neth.). 
29 by its reference to disputes of a "private law character." The claimants appealed this decision to the European Court of Human Rights.

In the case of the Haitian cholera victims, the United Nations publicly announced ${ }^{8}$ simply that the claims are "not receivable," suggesting that this is because considering them would necessarily include a review of political or policy matters. Thus far, the United Nations has declined to further explain the basis of its decision not to entertain such claims. The claimants while continuing to urge the Organization to establish a claims commission under the terms of the SOFA with Haiti to review these claims, have filed suit against the $\mathrm{UN}$ in the Federal District Court in New York.

Initially, the situations of the Mothers of Srebrenica and the Haitian cholera victims are very different. Failure to use military force, even where there is a policy or mandate to do so to protect innocent civilians, is very different from the failure to screen UN peacekeeping troops and negligent maintenance of sanitary facilities for those troops.

Admittedly, the use of force under a UN Security Council mandate is always a complex issue. These differences are inherently relevant and important to the issue of whether the actions of the UN troops that are at the heart of the claims of the Mothers of Srebrenica present a claim under Section 29 of a "private law character."

The European Court of Human Rights recently declared the application of the Mothers of Srebrenica inadmissible. In so doing, the Court upheld the immunity of the United Nations stating, in passing, that what was at issue were "operations established by the Security Council resolutions under Chapter VII of the United Nations Charter are fundamental to the mission of the United Nations to secure international peace and security." The Court added that, "the Convention (European Convention on Human Rights) cannot be interpreted in a manner that would subject the acts and omissions of the Security Council to domestic jurisdiction without the accord of the United Nations."

It is much more difficult to see how the new peacekeeping liability regime wouldn't apply to the Haitian cholera victims. More specifically, it is difficult to understand the United Nations' position ${ }^{9}$ that these claims "are not receivable." Indeed, as the head of the UN legal office that routinely handled claims against the Organization for some ten years, I did not recall any previous instance where such a formulation was utilized in regard to such claims. Recently, however, the Organization in 2011 used that formulation in response to claims against the Organization ${ }^{10}$ for damage to health suffered by third parties as a result of lead contamination in certain Internally Displaced Person camps in Kosovo. In that instance, the United Nations took the position that "[ $\mathrm{t}]$ he claims do not constitute claims of a private law character and, in essence, amount to a review of the performance of UNMIK's mandate as the interim administration in Kosovo. Based on the framework established by Member States, therefore, the claims are not receivable under Section 29 . . or . . the new peacekeeping liability regime."

It is important to note what appear to be certain critical distinctions between that situation and the Haiti situation. Initially, and perhaps most critical, is the fact that in Kosovo, the United Nations was not operating in the capacity simply of a "peacekeeping mission." It was acting in the capacity essentially of the temporary governmental authority - the "Interim Administration." In this context, in explaining its position, the United

\footnotetext{
8 Press Release, UN Secretary General, Haiti Cholera Victims' Compensation Claims 'Not Receivable' under Immunities and Privileges Convention, United Nations Tells Their Representatives, UN Press Release SG/SM/14828 (Feb. 21, 2013).

${ }^{9}$ UN Under-Secretary-General for Legal Affairs, Letter dated July 5, 2013 from the UN Under-Secretary for Legal Affairs addressed to Mr. Concannon (July 5, 2013).

${ }^{10}$ UN Under-Secretary-General for Legal Affairs, Letter dated July 25, 2011 from the UN Under-Secretary-General for Legal Affairs addressed to Madam on behalf of Roma, Ashkali and Egyptian residents of IDP camps in Mitrovica, Kosovo (July 25, 2011).
} 
Nations addressed other possibly critical factors relating to the long history of industrial pollution in the area and the precarious security situation in Kosovo.

Arguably, when the United Nations acts in such circumstances, it is the government for which it is temporarily acting that is ultimately responsible for such matters. In this respect, there is a much stronger case for characterizing the actions of the "Interim Administration" as addressing political or policy matters of a governmental nature that do not give rise to claims of a private law character within the meaning of Section 29, than there is in the Haiti situation.

\section{Remedies for harm caused by UN peacekeepers in regard to misconduct relating to sexual exploitation and abuse (SEA)}

Sexual exploitation and abuse by UN staff and officials and UN peacekeepers became a significant issue during the 1990s and early 2000s in connection with the increase in UN peacekeeping activities in the Balkans and Africa-particularly with widespread reports of such abuses by UN peacekeeping troops and civilian staff of the UN's mission in the Congo-MONUC-in 2004.

In 2003, in response to earlier reports of sexual exploitation of refugees by aid workers in West Africa, Secretary-General Kofi Annan issued an administrative issuance ${ }^{11}$ expressly prohibiting such conduct by UN staff, including the staff of the separately administered organs and programs of the United Nations. The issuance stipulates that any acts of sexual exploitation and abuse committed by UN staff members or persons under contract with the UN "constitute acts of serious misconduct and are therefore grounds for disciplinary measures, including summary dismissal."

In addition to disciplinary action, in cases where SEA has been determined to have occurred, the United Nations routinely considers referral of the matter to the national authorities of the perpetrator for prosecution or other appropriate action.

There was, however, a considerable loophole in the United Nations' response; the issuance did not cover UN peacekeeping troops. Neither were civilian police and military observers expressly covered in the issuance covered, until 2004 when the prohibitions in the issuance were specifically made applicable to them. In response to subsequent and more numerous reports of SEA, the Secretary General commissioned a report ${ }^{12}$ on the subject of SEA from a panel led by Ambassador Zeid of Jordan.

The Zeid report addressed a wide a wide spectrum of behavior ranging from solicitation of prostitutes, which was legal in some host countries, to acts considered criminal offenses in virtually all countries — such as rape and pedophilia. This included rape disguised as prostitution-for instance when the victim was given money or food to give the acts the appearance of consent. In addition to the issue of rape, there is also the issue of "peacekeeper babies" which is very difficult to address because of the absence often of an effective legal system in the host country.

Most importantly, the issue of addressing SEA is complicated by the fundamental nature of UN peacekeeping-where members of troop contributing contingents are under the exclusive authority of the commanders of those contingents - not the United Nations. The Zeid panel came up with a number of recommendations to address this problem. Unfortunately, the General Assembly declined to act on a number of those recommendations, primarily those relating to troop contingent Member States.

${ }^{11}$ UN Secretary General, Special measures for protection from sexual exploitation and sexual abuse, Secretary-General's Bulletin, UN Doc. ST/SGB/2003/13 (Oct. 9, 2003).

12 UN Secretary General, Letter dated Mar. 24, 2005 from the Secretary-General addressed to the President of the General As-

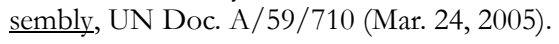


In a nutshell, the regime for military contingents is that complaints are referred to national contingents who are responsible for investigating and taking appropriate action. This usually involves repatriating the named individuals and following up in the troop contributing Member State. There is a responsibility on the part of the State that provides the peacekeeping forces to report the results of the investigation and follow up action to the United Nations.

Since the 2003 issuance and the Zeid report, the United Nations has implemented a number of important initiatives to address SEA in order to educate and sensitize both UN peacekeeping personnel and the local population as to what SEA is and the responsibility of the United Nations for responding to allegations of such misconduct, including the procedures for dealing with complaints, and measures for assisting the victims of SEA. Among these initiatives are the following:

- The Model Memorandum of Understanding ${ }^{13}$ to be used between troop-contributing states and the United Nations which includes specific provisions relating to SEA [A/61/19 (Part III, Annex)]

- United Nations Comprehensive Strategy on Assistance to Victims of Sexual Exploitation and Abuse $^{14}$ by UN staff and related personnel

- Criminal Accountability of United Nations Officials and Experts on Mission ${ }^{15}$ (relating to SEA) [A/Res/62/63 (January 8, 2008)]

In addition, the Secretary General has issued reports regarding the implementation of UN initiatives to address SEA, including an annual report ${ }^{16}$ on "Special measures for the protection from exploitation and sexual abuse." [See A/67/766 (April 2013).]

Unfortunately, as the latest annual report demonstrates, while the situation has improved, there continues to be problems with compliance by troop contributing states. According to the report, since 2005, the number of complaints has fallen from 373 to 88 in 2012.

However, the report also demonstrates that the greatest number of complaints continue to be in regard to peacekeeping troops and that there continues to be problems with the troop contributing states following up on the complaints.

In regard to remedies available to individuals harmed by this misconduct, the United Nations in its Comprehensive Strategy on Assistance specifically provides for basic assistance and support to both complainants and victims of SEA. Assistance and support takes the form of "medical care, legal services, support to deal with psychological and social effects of the experience and immediate material care, such as food, clothing, emergency and safe shelter." Children born as a result of SEA are to receive assistance with their individual needs, and the United Nations is to "work with Member States to facilitate, within their competence, the pursuit of claims related to paternity and child support."

Notably, the Comprehensive Strategy expressly provides at the outset: "The strategy shall in no way diminish or replace the individual responsibility for acts of sexual exploitation and abuse, which rests with the perpetrators. The Strategy is not intended as a means for compensation." As this provision suggests, SEA is

13 UN General Assembly, Report of the Special Committee on Peacekeeping Operations and its Working Group on the 2007 resumed session, UN Doc. A/61/19 (June 12, 2007).

${ }^{14}$ UN Comprehensive Strategy on Assistance and Support to Victims of Sexual Exploitation and Abuse by UN Staff and Related Personnel, GA Res. 62/214 (Dec. 21, 2007).

${ }^{15}$ GA Res. 62/63 (Dec. 6, 2007).

${ }^{16}$ UN Secretary-General, Special Measures for Protection from Sexual Exploitation and Sexual Abuse, UN Doc. A/67/766 (Feb. $28,2013)$. 
considered in the same manner as ordinary criminal acts by UN personnel—not UN actions for which the United Nations might be liable to third parties.

The United Nations throughout the decades since its establishment and notwithstanding the immunity provided it to perform its important functions, has generally achieved the objective of acting as a good citizen on the world stage in responding to third-party claims, including in the peacekeeping context. However, the situation in the Mothers of Srebrenica matter and the Haiti Cholera victims case, raise the issue of whether the Organization is continuing to do so and the implications of its position in these matters for the future of UN peacekeeping. 